TEACHING TACTIC

\title{
What? No Piercing? An Undergraduates' Guide to Biblical Law
}

\author{
Giovanna Czander \\ Dominican College
}

\section{The context}

Dominican College of Blauvelt is an independent four-year and graduate studies liberal arts college in Orangeburg, NY. The college is a Hispanic-Serving Institution. The total enrollment is just over $1860,74 \%$ of which are undergraduate students.

\section{The pedagogical purpose}

For years, I have struggled to effectively teach biblical law, the topic of my own scholarship, to undergraduate students. Students' increasingly disengaged reaction to biblical law was frustrating. How could students not see how interesting this topic actually is? How could they not realize what valuable skills could be gained by studying biblical law? How could they not take advantage of the theological concepts underlying biblical laws that would be so valuable in their own ethical and affective lives? The fact that I was successful in teaching at least the basic concepts and dynamics of biblical law to my graduate students, however, kept nudging me. How could this topic also be successfully taught to undergraduates?

A Wabash Center workshop for pre-tenured faculty and a Wabash Summer Grant to work on the intersection between my scholarship and teaching offered insights and tools. I designed a module devoted to biblical law for my Introduction to the Old Testament undergraduate class.

The project goals were: (1) To create and scaffold, in a new way, assignments, worksheets, and activities to introduce students to the content, shape, and dynamics of biblical law; and (2) to identify ways in which students would invest in learning about biblical law. 


\section{Description of the strategy}

The first major guiding insight is that reading is a complex activity. Undergraduates need a more detailed breakdown of tasks to perform when "reading" something. In a packet of worksheets on selected biblical laws I asked questions that analyzed them from different perspectives (historical-critical, sociological, literary, theological, etc.) and engaging different skills (such as those in Bloom's revised taxonomy: remembering, comprehending, applying, analyzing, evaluating, creating [Nilson, Teaching at Its Best, 2010]). The packet also provided continuity between assignments on biblical law and showed that biblical law is a relevant topic.

Students begin by considering the many rules we are surrounded by since childhood. They read an excerpt from All I Need to Know about Life I Learned in Kindergarten, by Robert Fulghum. After separating rules that mean the same thing they meant when they were in kindergarten from those that have acquired a different layer of meaning, students reflect on the specific rules they grew up with-which rules were hated? What did they do about it? This creates a sense of familiarity and personal engagement.

Then comes the "shock therapy," designed to both challenge previous knowledge and preconceptions on biblical law and function as a "hook" for students to immediately relate to the material. Students are generally familiar with the ten commandments and with the "eye for an eye" principle (though not correctly understood). They assume that biblical laws either do not apply to them or are about "what not to do." A few questions immediately challenge these assumptions: Does anyone have tattoos? Piercings? Does anyone like cheeseburgers? Bacon? Do you wear any mixed fabric clothing? Do you know that these are forbidden in the Bible? Does it matter to you? These questions and a clip from West Wing on the problematic consequences of a literal application of biblical laws capture students' curiosity and convey that most biblical laws are not to be understood literally, and that they may have functions beyond prescription.

\section{Why it is effective}

The scaffolded analysis of the laws requires the use of different skills to achieve the goals listed in Bloom's revised taxonomy. For the creative component students tweet the law to their friends (using the underlying principle identified in that law) and create a law of their own using the "What if . . . ?" logic employed in casuistic (= case-based) biblical laws. Peer-learning and team-building are fostered as students work in teams to analyze and discuss questions on biblical laws.

Piloting the newly designed module on biblical law produced both expected and unexpected results. As expected, students were more interested in the topic and related to the texts. However, the results of the assessment were below expectations. What was utterly surprising were the final papers and brief presentations students did on how the study of a specific biblical law affected their lives. Nearly all the students found that biblical laws, beyond their literal off-putting formulation, are indeed closer to their own lives and, in some cases, enhance and nuance their understanding of God. Not every student emphasized a theological insight related to their law but all did find a value that was relevant to their lives and society. The depth of personal engagement with the laws was completely unexpected.

Students were surprised by the many possible ways one can look at laws. In a final non-graded anonymous assessment of the module, they agreed that the study of biblical law develops critical thinking skills, enhances detailed analysis, and involves metacognitive skills. Most importantly, they took away the idea that biblical laws are not there to be practiced as stated, but are there to be explored, analyzed, and dissected until they reveal their underlying principles and values. Students learned that biblical law is not just about life in general, or life in ancient times, but is about their own life. This confirmed my hypothesis that the study of biblical laws is a pedagogical gold mine but needs to be prospected carefully and with the correct tools. 